\title{
Added value of serial bio-adrenomedullin measurement in addition to lactate for the prognosis of septic patients admitted to ICU
}

\author{
Alice Blet ${ }^{1,2}$, Charles de Roquetaillade ${ }^{1,2}$, Oliver Hartmann ${ }^{3}$, Joachim Struck ${ }^{3}$, Alexandre Mebazaa ${ }^{1,2}$, \\ Benjamin Glenn Chousterman ${ }^{1,2^{*}}$ and on behalf of the Adrenoss-1 study investigators
}

To the editor:

Sepsis mortality decreased over the last decades, although it remains dramatically high [1]. The implementation of guidelines such as the Surviving Sepsis Campaign (SSC) contributed to these progresses. SSC recommends to guide resuscitation on normalization of lactate levels [2]. Guiding resuscitation on lactate reduction is highly debated [3]. Anyway, normalization of lactate is associated with improved outcome [4]. We have recently shown that plasma levels of bio-adrenomedullin (bio$\mathrm{ADM})$, a peptide regulating vascular integrity and endothelial function, were associated with patient outcome during sepsis [5]. Interestingly, we observed that patients with elevated bio-ADM levels at admission and with low bio-ADM levels 2 days later had similar outcome to patients with persistently low bio-ADM levels. We therefore aimed to evaluate the added value of bio-ADM to lactate measurement in the AdrenOSS-1 cohort.

The AdrenOSS-1 study is a prospective observational study conducted in 24 centers within 5 European countries and included 583 septic patients from June 2015 to May 2016 [5]. The primary endpoint was 28-day mortality. We evaluated the relationship between the association of initial evolution of lactate plasma levels and bio-ADM level at $24 \mathrm{~h}$ and outcome in patients for whom both markers were available at admission and 1 day later ("24h"). As described previously, bio-ADM levels below or above $70 \mathrm{pg} / \mathrm{mL}$ were considered respectively as low and high [5].

In patients with high lactate levels $(>2 \mathrm{mmol} / \mathrm{L})$ at admission $(n=328)$ (Table 1$)$, lactate normalization $(<2 \mathrm{mmol} / \mathrm{L})$ at $24 \mathrm{~h}$ was associated with better outcome than in patients with persistently high lactate at 24 h (28-day mortality $15.9 \%$ vs $41.9 \%$ respectively, HR 3.3 [2.0-5.3], $p<0.001$ ) (Fig. 1).

Interestingly, among patients with decreasing lactate, high and low bio-ADM levels at $24 \mathrm{~h}$ identified patients with substantially different outcomes (28-day mortality $7 \%$ vs $26 \%$ for low vs high bio-ADM respectively, HR 4.4 [1.6-11.7], $p<0.005$ ) (Fig. 1). High and low bio-ADM levels at $24 \mathrm{~h}$ also differentiated outcome of patients with persistently elevated lactate (HR 4.5 [1.6-12.3], $p<0.005)$.

In patients with low initial lactate $(n=234$ admitted and $n=171$ alive at $24 \mathrm{~h}$ ), overall 28-day mortality was $11.2 \%$, neither lactate nor bio-ADM added prognostic value.

For all analyses, similar results were obtained, when missing $24 \mathrm{~h}$ data were replaced by the last available values.

Accordingly, our data suggest that measurement of bio-ADM in addition to lactate may help physicians to refine risk stratification and therefore to guide resuscitation during sepsis.

\footnotetext{
* Correspondence: benjamin.chousterman@aphp.fr

'Department of Anesthesiology and Critical Care, Hôpital Lariboisière, DMU

Parabol, APHP.Nord, Paris, France

${ }^{2}$ Inserm U942 MASCOT, Université de Paris, Paris, France

Full list of author information is available at the end of the article
} 


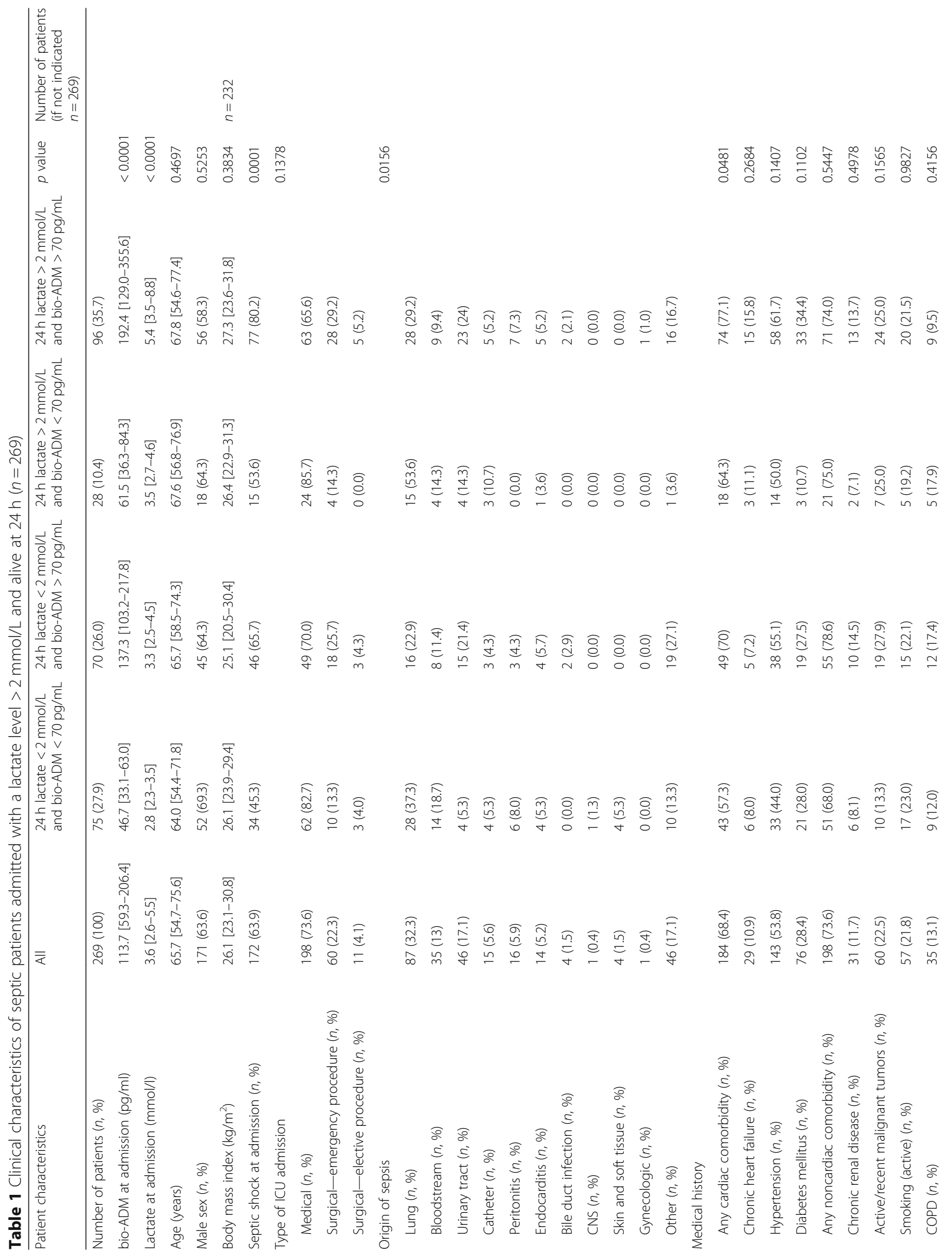




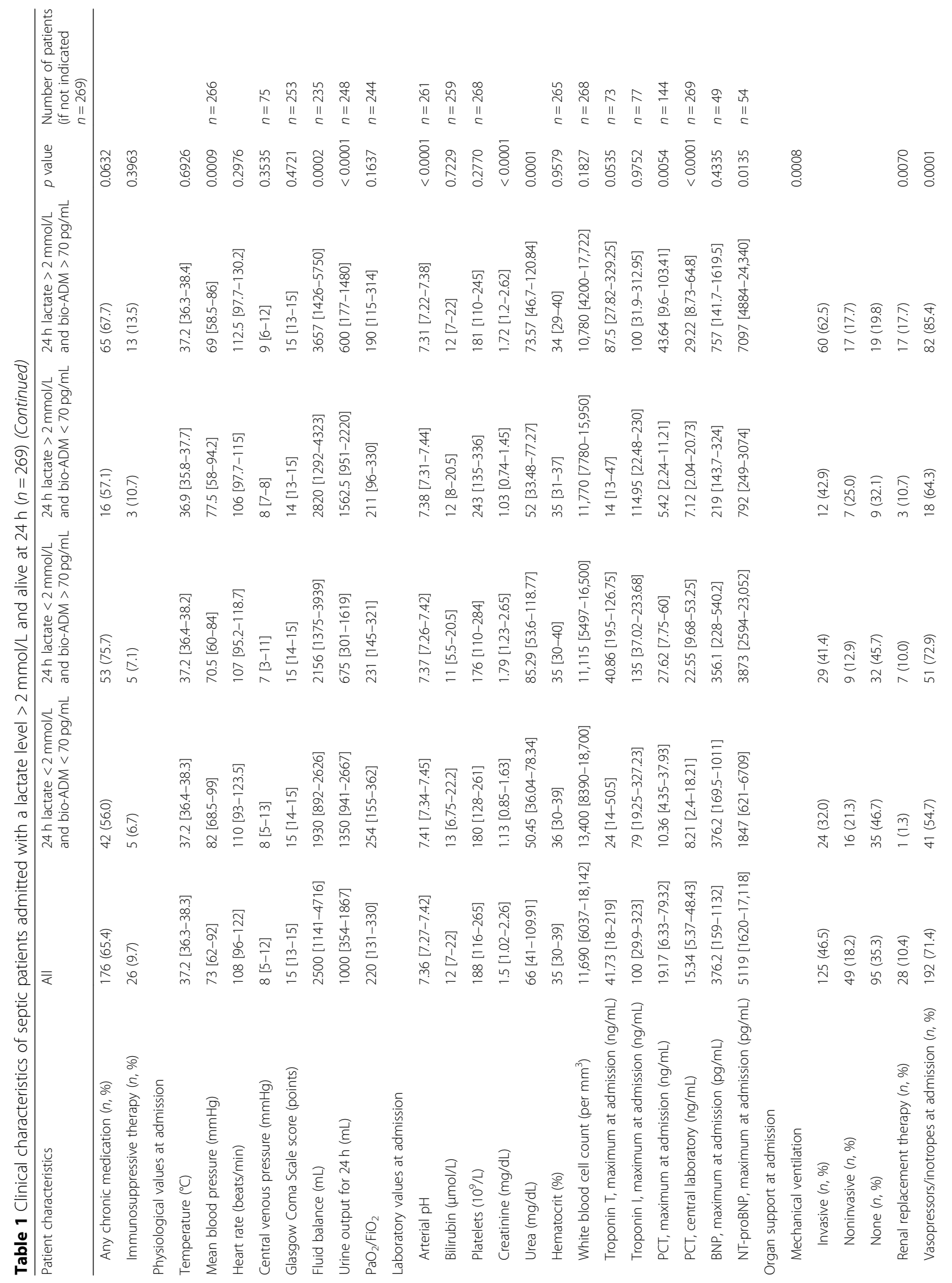




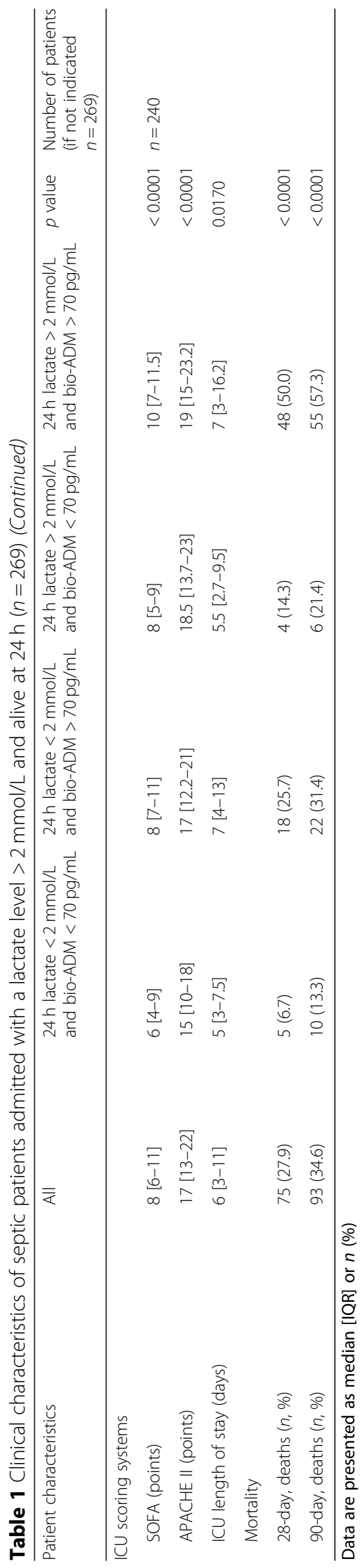



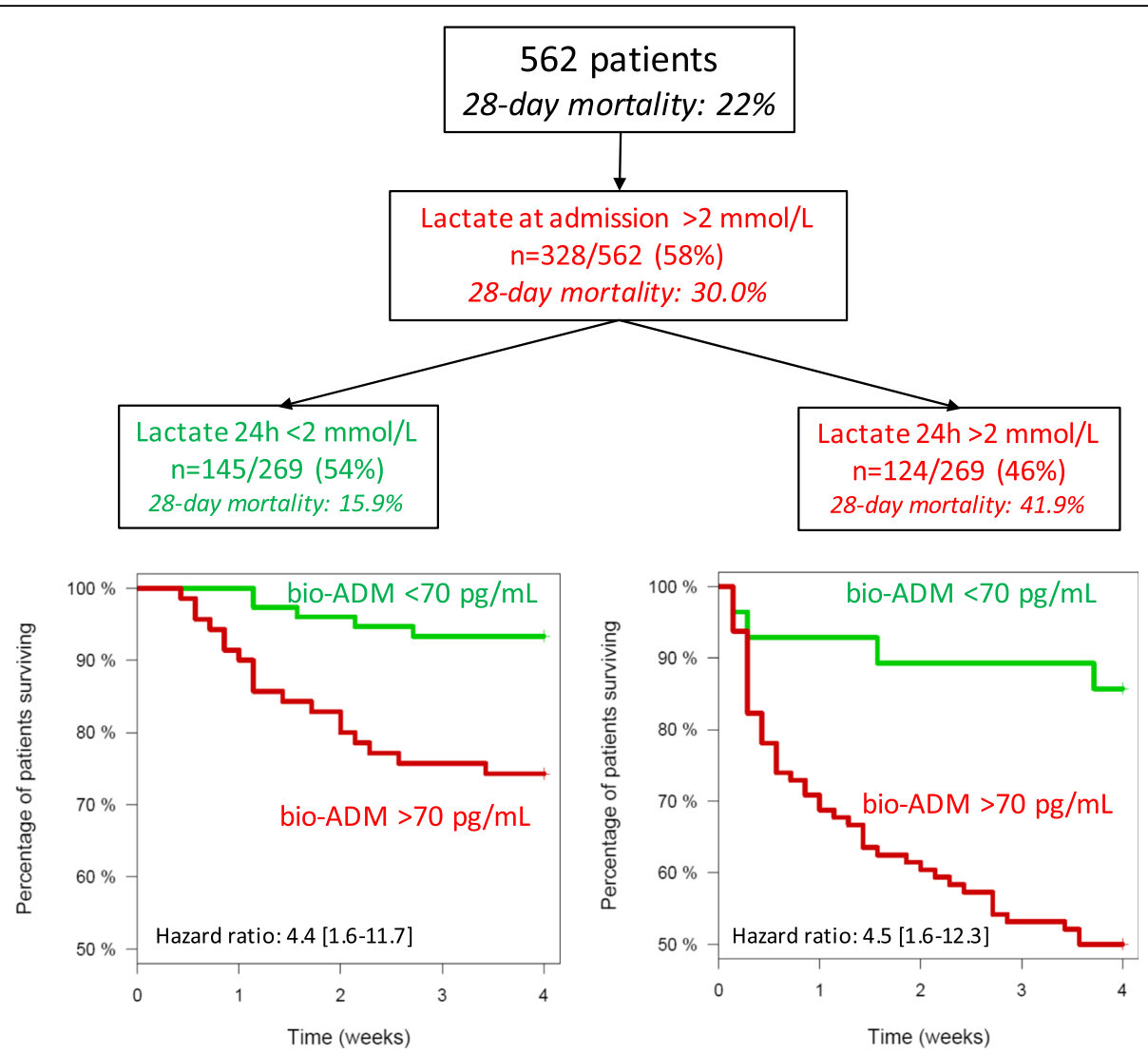

Fig. 1 Impact of $24 \mathrm{~h}$ lactate and bio-ADM values in patients with elevated lactate level at admission. The green curve in the left KM-plot illustrates data from 75 patients with 5 events, the red curve 70 patients with 18 events. The green curve in the right KM-plot illustrates data from 28 patients with 4 events, the red curve 96 patients with 48 events. Of note, differences in numbers between admission $(n=328)$ and $24 \mathrm{~h}(n=$ 269) is related to initial mortality

\section{Acknowledgements}

The authors are particularly grateful to Marie-Céline Fournier, who coordinated organizational aspects of the study. The authors also thank the Centre de Recherche Clinique (CRC) of Lariboisière University Hospital for support. Listing of site investigators of the AdrenOSS-1 study:

AdrenOSS-1 study investigators:

Belgium, Brussels: Pierre-François Laterre, Caroline Berghe, Marie-France Dujardin, Suzanne Renard, Xavier Wittebole, Christine Collienne, Diego Castanares Zapatero; Ottignies: Thierry Dugernier, Marco Vinetti, Nicolas de Schryver, Anne Thirifays, Jacques Mairesse; Haine-St-Paul: Vincent Huberlant, Hélène Petre, Isabelle Buelens, Pierre Henin, Hugues Trine, Yves Laurent, Loix Sébastien, Paul Geukens, Laurent Kehl. France, Limoges: Bruno François, Philippe Vignon, Nicolas Pichon, Emmanuelle Begot, Anne-Laure Fedou, Catherine Chapellas, Antoine Galy, Nicolas Rodier, Ludmilla Baudrillart, Michelle Nouaille, Séverine Laleu, Claire Mancia, Thomas Daix, Paul Bourzeix Isabelle Herafa, Anne-Aurore Duchambon; La Roche sur Yon: Jean Baptiste Lascarrou, Maud Fiancette, Gwenhael Colin, Matthieu Henry-Lagarrigue, JeanClaude Lacherade, Christine Lebert, Laurent Martin-Levfèvre, Isabelle Vinatier, Aihem Yehia, Konstantinos Bachoumas, Aurélie Joret, Jean Reignier, Cécille Rousseau, Natacha Maquigneau, Yolaine Alcourt, Vanessa Erragne Zinzonni, Angélique Deschamps, Angelina Robert; Tours: Emmanuelle Mercier, Véronique Simeon-Vieules, Aurélie Aubrey, Christine Mabilat, Denis Garot, Stephan Ehrmann, Annick Legras, Manikikian, Youenn Jouan, Pierre-François Dequin, Antoine Guillon, Laetitia Bodet-Contentin, Emmannuelle Rouve, Charlotte Salmon, Lysiane Brick, Stéphanie Massat; Angoulême: Arnaud Desachy, Marie Anne Fally, Laurence Robin, Christophe Cracco, Charles Lafon, Sylvie Calvat, Stéphane Rouleau, David Schnell; Angers: Sigismond Lasocki, Philippe Fesard, Damien Leblanc, Guillaume Bouhours, Claire Chassier Mathieu Conte, Thomas Gaillard, Floriane Denou, Mathieu Kerymel, Marion
Guyon, Anthéa Loiez, Stéphanie Lebreton; Strasbourg - Nouvel Hôpital Civil: Ferhat Meziani, Hayat Allam, Samir Chenaf, Hassène Rahmani, Sarah Heenen, Christine Kummerlen, Xavier Delabranche, Alexandra Boivin, Raphaël ClereJehl, Yannick Rabouël; Strasbourg - Hôpital HautePierre: Julien Pottecher, Sophie Bayer, Catherine Metzger, Stéphane Hecketsweiler, Pierre Olivier Ludes, Hortense Besancenot, Nadia Dhif, Guy Freys, Jean-Marc Lessinger, Anne Launoy, Aude Ruimy, Alain Meyer, M. Szozot; Paris - Hôpital Lariboisière: Alexandre Mebazaa, Nicolas Deye, Etienne Gayat, Marie-Céline Fournier, Sarra Abroug, Badr Louadah, Elodie Feliot, Sebastian Voicu, Isabelle Malissin, Bruno Megarbane, Philippe Manivet, Gardianot Victori, Da Silva Kelly, Béatrice La Foucher, Valérie Pierre, Lamia Kerdjana, Thomas Beeken, Antoine Goury, Pierre Garcon, Samuel Gaugain, Benjamin Glenn Chousterman, Benjamin Huot, Romain Barthelemy, Benjamin Soyer; Paris - Hôpital St Louis: Laurent Jacob, Matthieu Legrand, Marie-Céline Fournier, Francine Bonnet, Chloé Legall, Haikel Oueslati, Alexandru Cupaciu, Philippe Manivet, Badr Louadah; Paris - Hôpital Bichat: Romain Sonneville, Sophie Letrou, Lila Bouadma, Bruno Mourvillier, Véronique Deiler, Eric Magalhaes, Mathilde Neuville, Jean-François Timsit, Aguila Radjou; Colombes: Stéphane Gaudry, Emeline Dubief, Jonathan Messika, Béatrice La Combe, Damien Roux, Guillaume Berquier, Mohamed Laissi, Jean-Damien Ricard; Clermont Ferrand: Jean-Michel Constantin, Sebastien Perbet, Julie Delmas, Julien Pascal, Sophie Cayot, Renaud Guerin, Matthieu Jabaudon, Laurence Roszyk, Christine Rolhion, Justine Bourdier, Mathilde Lematte, Charlène Gouhier, Camille Verlhac, Thomas Godet, Sophiano Radji, Elodie Caumon, Sandrine Thibault. Germany, Aachen: Nikolaus Marx, Tobias Schuerholz, Jessica Pezechk, Florian Feld, Christian Brülls, Thorben Beeker, Tim-Philipp Simon, Robert Deisz, Achim Schindler, Bianca Meier, Thorsten Janisch; Köln: Andreas Hohn, Dirk Schedler, Wolfgang Wetsch, Daniel Schröder; Erfurt: Andreas Meier-Hellmann, Alexander Lucht, Robert Henker, Magdalena Römmer, Torsten Meinig; Frankfurt: Kai D. Zacharowski, 
Patrick Meybohm, Simone Lindau, Haitham Mutlak; Hamburg: Stefan Kluge, Grit Ringeis, Birgit Füllekrug, Brigitte Singer, Axel Nierhaus, Katrin Bangert, Geraldine de Heer, Daniel Frings, Valentin Fuhrmann, Jakob Müller, Jörg Schreiber, Barbara Sensen, Stephanie Siedler, Annekatrin Siewecke, Gerold Söffker, Dominic Wichmann, Mélanie Kerinn; Augsburg: Ulrich Jaschinski, llse Kreuser, Marlene Zanquila; Jena: Andreas Kortgen, Frank Bloos, Falk Gonnert, Daniel Thomas-Rüddel, Anja Haucke, Steffi Kolanos, Karina Knuhr Kohlberg, Petra Bloos, Katrin Schwope; Italy, Rome: Sant'Andrea Hospital: Salvatore Di Somma, Marino Rossella, Veronica Russo, Santarelli Simona, Christopher Bartoli, Sylvia Navarin, Cristina Bongiovanni, Michela Orru, Daniela Quatrocchi, Giada Zoccoli, Antonella Varchetta; Rome - Policlinico Universitario A. Gemelli: Massimo Antonelli, Gennaro de Pascale, Maria Sole Vallecoccia, Salvatore Lucio Cutuli, Valentina Digravio, Daniela Quattrochi, Sonia D'Arrigo, Filippo Elvino Leone; The Netherlands, Enschede: Bert Beishuizen, Martin Rinket, Natalie Border, Mariska Bos-Burgmeijer, Astrid Braad, S. Papendorp, Alexander Cornet, J. Vermeijden, Ronald J Trof; Nijmegen: Peter Pickkers, Marieke van de A, Helen Van Wezel, Leo Heunks, Natalie Border, Chantal Luijten-Arts, Astrid Hoedemaekers, Hans van der Hoeven, Noortje Roovers, Pleun Hemelaar.

\section{Ethics declarations}

Charles de Roquetaillade works as a resident in the Saint Louis Lariboisière University Hospitals. Alice Blet is an attending physician in the Department of Anesthesiology and Critical Care of Saint Louis Lariboisière University Hospitals. Oliver Hartmann and Joachim Struck are employees of sphingotec $\mathrm{GmbH}$, the company that developed and holds patent rights in the bio-ADM assay. The other authors are members of the steering committee and/or investigators in the Adrenoss study.

\section{Authors' contributions}

All authors contributed to the study concept and design. BC, EG, AM, and JS contributed to the acquisition of data. $B C, A B, C R, O H, J S, E G$, and $A M$ contributed to the analysis and interpretation of data. BS, JS, and AM drafted the manuscript. All authors critically revised the manuscript for important intellectual content. OH contributed to the statistical analysis. EG and AM obtained funding. EG and AM provided administrative, technical, or material support. EG and AM supervised the study. All authors read and approved the final manuscript.

\section{Authors' information}

Sponsoring

sphingotec $\mathrm{GmbH}$

Neuendorfstraße 15a

16761 Hennigsdorf

Germany

Management

European Drug Development Hub (EDDH), Vandoeuvres Les Nancy:

Stéphanie Grojean, Laetitia Tourneur, Virginie Barthel

\section{Funding}

AdrenOSS-1 (ClinicalTrials.gov identifier NCT02393781) was funded by sphingotec GmbH, Neuendorfstraße 15a, 16761 Hennigsdorf, Germany. This project has received funding from the European Union's Horizon 2020 research and innovation program under grant agreement 666328.

\section{Availability of data and materials}

AM had full access to all data in the study and take responsibility for the integrity of the data and the accuracy of the data analysis.

\section{Ethics approval and consent to participate}

The present study was conducted in France, Belgium, The Netherlands, Italy, and Germany. The study protocol was approved by the local ethics committees, and the study was conducted in accordance with Directive 2001/20/EC as well as good clinical practice (International Conference on Harmonization Harmonized Tripartite Guideline version 4 of May 1, 1996, and decision of November 24, 2006) and the Declaration of Helsinki. Patients were included from June 2015 to May 2016.

\section{Consent for publication}

Not applicable.

\section{Competing interests}

AM has received speaker's honoraria from Novartis, Orion, and Servier and fees as a member of the advisory board and/or steering committee from Cardiorentis, Adrenomed, sphingotec, Sanofi, Roche, Abbott, and BristolMyers Squibb. EG has received consulting fees from Adrenomed, Roche Diagnostics, and Magnisense and lecture fees from Edwards Lifesciences. $\mathrm{OH}$ and IS are employees of sphingotec $\mathrm{GmbH}$, the company that developed and holds patent rights in the bio-ADM assay. BC received fees as a member of an advisory board from Roche Diagnostics. The other authors declare that there are no competing interests.

\section{Author details}

'Department of Anesthesiology and Critical Care, Hôpital Lariboisière, DMU Parabol, APHP.Nord, Paris, France. ${ }^{2}$ Inserm U942 MASCOT, Université de Paris, Paris, France. ${ }^{3}$ Sphingotec GmbH, Hennigsdorf, Germany.

Received: 14 January 2020 Accepted: 17 February 2020

Published online: 28 February 2020

\section{References}

1. Fleischmann C, Scherag A, Adhikari NK, Hartog CS, Tsaganos T, Schlattmann $P$, et al. Assessment of global incidence and mortality of hospital-treated sepsis. Current estimates and limitations. Am J Respir Crit Care Med. 2016;193(3):259-72.

2. Levy MM, Evans LE, Rhodes A. The Surviving Sepsis Campaign Bundle: 2018 update. Crit Care Med. 2018:46(6):997-1000.

3. Hernandez G, Bellomo R, Bakker J. The ten pitfalls of lactate clearance in sepsis. Intensive Care Med. 2019:45(1):82-5.

4. Vincent JL, Quintairos ESA, Couto L Jr, Taccone FS. The value of blood lactate kinetics in critically ill patients: a systematic review. Crit Care. 2016;20(1):257.

5. Mebazaa A, Geven C, Hollinger A, Wittebole X, Chousterman BG, Blet A, et al. Circulating adrenomedullin estimates survival and reversibility of organ failure in sepsis: the prospective observational multinational Adrenomedullin and Outcome in Sepsis and Septic Shock-1 (AdrenOSS-1) study. Crit Care. 2018;22(1):354.

\section{Publisher's Note}

Springer Nature remains neutral with regard to jurisdictional claims in published maps and institutional affiliations.
Ready to submit your research? Choose BMC and benefit from:
- fast, convenient online submission
- thorough peer review by experienced researchers in your field
- rapid publication on acceptance
- support for research data, including large and complex data types
- gold Open Access which fosters wider collaboration and increased citations
- maximum visibility for your research: over $100 \mathrm{M}$ website views per year
At BMC, research is always in progress.
Learn more biomedcentral.com/submissions 